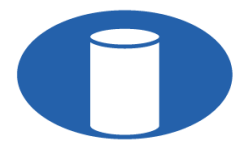

IBRACON Structures and Materials Journal

Revista IBRACON de Estruturas e Materiais

IBRACON

ISSN 1983-4195

ismj.org

ORIGINAL ARTICLE

\title{
Experimental assessment of accelerated test methods for determining chloride diffusion coefficient in concrete
}

\section{Avaliação experimental de métodos acelerados de determinação do coeficiente de difusão de cloretos no concreto}

Félix Krolow Sell Junior ${ }^{\mathrm{a}}$ (D)

Gustavo Bosel Wally,c

Fernando Ritiéle Teixeira, ${ }^{\text {a,c }}$ (D)

Fábio Costa Magalhães ${ }^{\mathrm{c}, \mathrm{d}}(\mathbb{D}$

\begin{abstract}
${ }^{a}$ Universidade Federal de Pelotas - UFPel, Centro de Desenvolvimento Tecnológico, Programa de Pós-graduação em Ciência e Engenharia de Materiais, Pelotas, RS, Brasil

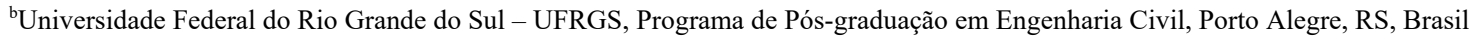
'Instituto Federal de Ciência e Tecnologia do Rio Grande do Sul - IFRS, Laboratório de Estruturas e Materiais de Construção Civil, Rio Grande, RS, Brasil

${ }^{\mathrm{d}}$ Universidade Federal de Rio Grande - FURG, Escola de Engenharia, Programa de Pós-graduação em Engenharia Oceânica, Rio Grande, RS, Brasil
\end{abstract}

Received: 08 May 2020

Accepted: 14 September 2020

\begin{abstract}
The performance of accelerated test methods to determine the chloride diffusion coefficient in concrete is an important tool in the evaluation of the durability-related properties of the material and in the service life prediction of structures. In this way, this paper presents an experimental assessment of three standardized test methods for determining chloride diffusion coefficient. The migration-based tests presented by NT Build 492 and UNE 83987 and the diffusion-based test presented by ASTM C1556 were carried out. Six concrete mixes were produced: three with different water/binder ratios $(0.45,0.55$, and 0.65$)$ and three with replacement of cement by silica fume in the levels of 5,10, and $20 \%$. The results indicate that the method standardized by NT Build 492 has the best correlation with the diffusion test, in addition to being the one that requires the shortest execution time and has the lowest coefficient of variation of the results.
\end{abstract}

Keywords: chloride diffusion coefficient, accelerated test methods, concrete durability.

Resumo: A realização de ensaios acelerados de determinação do coeficiente de difusão de cloretos no concreto é uma importante ferramenta na avaliação das características relacionadas à durabilidade do material e na previsão da vida útil das estruturas. Nesse sentido, este trabalho apresenta uma avaliação experimental de três metodologias normatizadas de determinação do coeficiente de difusão do concreto. Foram realizados os ensaios de migração iônica apresentados pela NT Build 492 e pela UNE 83987 e o ensaio de difusão regido pela ASTM C1556. Seis traços de concreto foram produzidos, sendo três com diferentes relações água/aglomerante $(0,45,0,55$ e 0,65$)$ e três com substituição de cimento por sílica ativa nos teores de 5,10 e $20 \%$. Os resultados indicam que o método normatizado pela NT Build 492 apresenta a melhor correlação com o ensaio de difusão, além de ser o que requer menor tempo de execução e apresentar menor coeficiente de variação dos resultados.

Palavras-chave: coeficiente de difusão de cloretos, métodos acelerados, durabilidade do concreto.

How to cite: F. K. Sell Junior, G. B. Wally, F. R. Teixeira, and F. C. Magalhães, "Experimental assessment of accelerated test methods for determining chloride diffusion coefficient in concrete", IBRACON Struct. Mater. J., vol. 14, no. 4, e14407, 2021, https://doi.org/10.1590/S198341952021000400007

Corresponding author: Gustavo Bosel Wally. E-mail: gustavo.wally@gmail.com

Financial support: This study was financed in part by the Coordenação de Aperfeiçoamento de Pessoal de Nível Superior - Brasil (CAPES) - Finance Code 001. Conflict of interest: Nothing to declare. 


\section{INTRODUCTION}

The determination of the chloride diffusion coefficient in concrete is a common practice, since the diffusivity can be taken as an indicator of the resistance of concrete to the chloride penetration, as well as used as an input parameter in service life prediction models. The transport of chloride ions through concrete, however, is a complex issue, implying the development of a wide range of tests aimed at determining the diffusion coefficient, each having its own particularities and limitations [1], [2].

In parallel, the importance of the performance-based approach for concrete durability has recently been promoted and discussed worldwide [3], [4]. This is because the prescriptive approach traditionally adopted in durability design is limited to stipulating parameters such as minimum cement content, minimum compressive strength, and maximum water/binder (w/b) ratio [5]. It should be noted that NBR 6118 [6] presents the idea of a performance-based approach, however, without mentioning any test method, not even reference values for the validation of the results. In the performance-based approach, it is desirable to evaluate at least one parameter that reflects the general durability-related properties of concrete when in its early ages, such as the diffusion coefficient, in a similar way to the compressive strength assessed at 28 days, which is a simple and relative index that reflects the compressive strength and general mechanical properties of concrete [7]. However, although quick results are always desirable in engineering applications, it is known that the chloride penetration into concrete occurs at very low rates [8].

In this sense, steady state and non-steady state migration test methods, as well as methods based on the electrical resistivity of the material, have been widely used internationally as accelerated tests to evaluate the chloride diffusivity in concrete [9]. These tests, despite not imposing real exposure conditions on concrete, in which a multiplicity of actions occurs simultaneously and randomly, make it possible to obtain results in less time and involve lower operating costs [10]. However, due to the complexity of the transport mechanisms involved in the chloride penetration process, there is still a lack of data on correlations between the results obtained from different test methods, whether based on migration, resistivity, or diffusion. In the literature, experimental data to establish these correlations are also limited [11].

In this context, this paper evaluates the characteristics, results and correlations of three different standardized test methods for determining chloride diffusion coefficient in concrete. The migration tests standardized by NT Build 492 [12] and UNE 83987 [13] and the diffusion test governed by ASTM C1556 [14] were carried out. For the analysis, six different concrete mixes were produced: three with different $\mathrm{w} / \mathrm{b}$ ratios $(0.45,0.55$, and 0.65$)$, and three with partial replacement of cement by silica fume in the levels of 5, 10, and $20 \%$.

\section{METHODOLOGY}

\subsection{Materials}

Brazilian Portland cement CP II Z-40, natural quartz sand, gravel, silica fume, polyfunctional additive, and potable water were used to produce the concretes. The aggregates used are in accordance with the NBR 7211 [15] and their physical characteristics are shown in Table 1.

Table 1. Physical characterization of the aggregate.

\begin{tabular}{cccc}
\hline Parameter & Fine sand & Medium sand & \multicolumn{2}{c}{ Coarse aggregate } \\
\hline Fineness modulus & $1.64^{\mathrm{a}}$ & $2.42^{\mathrm{a}}$ & $6.71^{\mathrm{a}}$ \\
\hline Maximum diameter $(\mathrm{mm})$ & $2.40^{\mathrm{a}}$ & $2.40^{\mathrm{a}}$ & $12.50^{\mathrm{a}}$ \\
\hline Specific gravity $\left(\mathrm{g} / \mathrm{cm}^{3}\right)$ & $2.67^{\mathrm{b}}$ & $2.65^{\mathrm{b}}$ & $2.65^{\mathrm{c}}$ \\
\hline Loose unit mass $\left(\mathrm{g} / \mathrm{cm}^{3}\right)$ & $1.39^{\mathrm{d}}$ & $1.53^{\mathrm{d}}$ & $1.46^{\mathrm{d}}$ \\
\hline
\end{tabular}

a -NBR NM 248 [16], ${ }^{\mathrm{b}}-\mathrm{NBR}$ NM 52 [17], ${ }^{\mathrm{c}}$-NBR NM 53 [18], ${ }^{\mathrm{d}}-\mathrm{NBR}$ NM 45 [19].

The choice of CP II Z-40 cement was because it is the type of cement most easily found in the local market for use in structural elements, has a low content of pozzolanic addition and presents a better performance to Portland cement without additions in terms of durability. The polyfunctional additive adopted is free of chlorides and its specific gravity can vary between 1.14 and $1.20 \mathrm{~g} / \mathrm{cm}^{3}$. The silica fume, in turn, was chemically characterized by means of energy dispersive X-ray analysis (EDX) and its composition is shown in Table 2. 
Table 2. Chemical characterization of silica fume.

\begin{tabular}{ccccccc}
\hline Component & $\mathbf{S i O}_{2}$ & $\mathbf{K}_{\mathbf{2}} \mathbf{O}$ & $\mathbf{C a O}$ & $\mathbf{F e}_{2} \mathbf{O}_{\mathbf{3}}$ & $\mathbf{M n O}$ & Others \\
\hline Content $(\%)$ & 88.32 & 6.14 & 4.35 & 0.68 & 0.39 & 0.12 \\
\hline
\end{tabular}

\subsection{Mix design and concrete production}

The concrete mix design was performed using the IPT/EPUSP [20] methodology. Through the experimental procedure, the ideal dry mortar content was defined at 52\% $(\alpha=0.52)$. The proportion of 1:1.6:2.4 (cement: sand: gravel) was defined. The value of $100 \pm 10 \mathrm{~mm}$ was adopted for concrete slump. The composition of concretes is shown in Table 3.

Table 3. Material consumption of the concrete mixes.

\begin{tabular}{ccccccc}
\hline & & \multicolumn{3}{c}{ Material consumption $\left(\mathbf{k g} / \mathbf{m}^{\mathbf{3}}\right)$} \\
\cline { 3 - 7 } Mix & w/b ratio & Cement & Silica fume & Fine sand & Medium sand & Coarse aggregate \\
& & & & & & \\
\hline R 45 & 0.45 & 400.00 & 0.00 & 128.00 & 512.00 & 960.00 \\
\hline SF 5 & 0.45 & 380.00 & 20.00 & 128.00 & 512.00 & 960.00 \\
\hline SF 10 & 0.45 & 360.00 & 40.00 & 128.00 & 512.00 & 960.00 \\
\hline SF 20 & 0.45 & 320.00 & 80.00 & 128.00 & 512.00 & 960.00 \\
\hline R 55 & 0.55 & 383.00 & 0.00 & 122.56 & 490.24 & 919.20 \\
\hline R 65 & 0.65 & 367.00 & 0.00 & 117.44 & 469.76 & 880.80 \\
\hline
\end{tabular}

The mixing of the concrete was carried out in accordance with NBR 5738 [21]. Sixteen specimens ( $\phi 100 \times 200 \mathrm{~mm})$ of each mix were produced. After molding, the specimens were subjected to submerged curing in a water tank saturated with lime and controlled temperature, according to the specifications of NBR 5738 [21], until the age of 120 days.

\subsection{Preparation and selection of samples}

The specimens intended for the tests to determine the chloride diffusion coefficient had to be cut to obtain samples with the dimensions recommended in the standard that governs each test method. The cut was performed on a watercooled diamond saw. The scheme of the cut of the specimens and the dimension of the samples destined for each test are presented in Figure 1. After being cut, all the slices had their sides waterproofed with epoxy paint. The samples used in the immersion test (ASTM C1556 [14]) also received the application of a thin layer of plastic mass and waterproofing the face opposite to the cut.

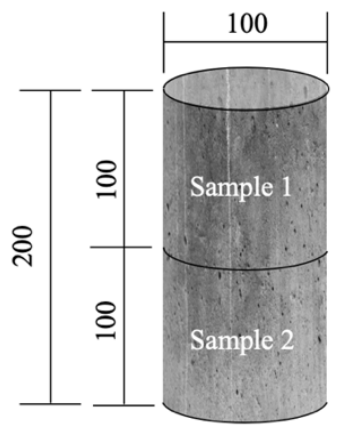

(a)

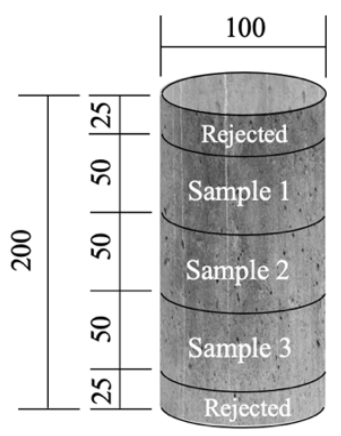

(b)

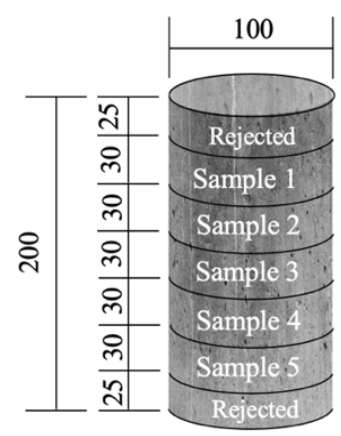

(c)

Figure 1. Sample cut scheme (dimensions in mm): (a) for ASTM C1556 [14] test method; (b) for NT Build 492 method; (c) for UNE 83987 [13] method. 
To avoid the use of samples with very different gravel and paste content, the mortar content of the samples was also determined. For this, an adaptation of ASTM E562 [22] was used, as proposed by Ribeiro [23]. Through this methodology it is possible to estimate the relative amount of a phase (coarse aggregate or mortar, for example) by overlaying a mesh on the sample and quantifying the nodes that appear on the evaluated phase. Nodes located on the transition zone are given 0.5 points, while nodes positioned on the analyzed phase receive 1 point. Finally, the percentage of the phase in the sample is obtained by the relationship between the number of points and the total knots of the mesh used. Figure 2 presents this methodology schematically.

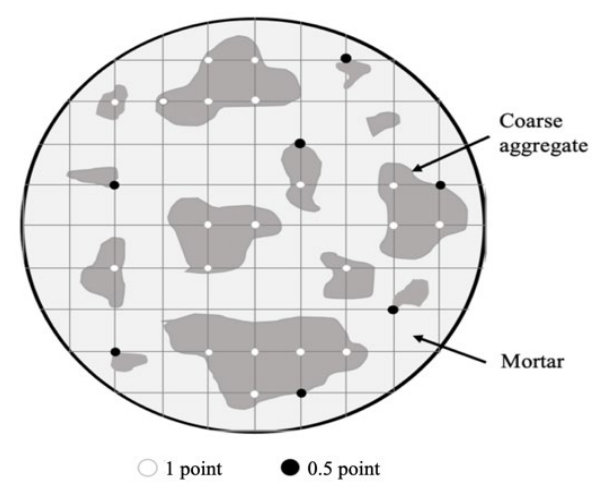

Figure 2. Methodology proposed by Ribeiro [23] to determine the relative percentage of a phase in the sample.

\subsection{Methods}

\subsubsection{Compressive strength and capillary water absorption}

Initially, to obtain preliminary data about the physical and mechanical characteristics of the concretes, the tests of compressive strength and capillary water absorption were carried out, following, respectively, the codes NBR 5739 [24] and NBR 9779 [25]. Both tests were performed 126 days after casting the concretes and in each test three specimens from each concrete mix were used.

\subsubsection{Apparent diffusion coefficient - Immersion test}

The test method standardized by ASTM C1556 [14] consists of immersing specimens in saline solution for a minimum period of 35 days. In this test, there is no imposition of a electric potential difference, with the ions entering the concrete given mostly by diffusion. Thus, among the tests covered in this study, this method is the closest to the exposure conditions imposed by a chloride-rich environment.

For the test, three samples of $\phi 100 \times 100 \mathrm{~mm}$ from each concrete mix were used. Before carrying out the test, all samples were saturated in calcium hydroxide solution for a minimum period of $24 \mathrm{~h}$, until mass constancy. During the test, which started 126 days after casting the concrete, all specimens were submerged for 112 days in saline solution with a concentration of $165 \mathrm{~g}$ de $\mathrm{NaCl}$ per liter of water and at a temperature of $23 \pm 2{ }^{\circ} \mathrm{C}$. After the immersion period, the samples were dried in air, at a controlled temperature of $23 \pm 2{ }^{\circ} \mathrm{C}$ for $24 \mathrm{~h}$.

After drying, the concrete powder was extracted for later determination of the chloride profiles. A vertical drill was used with an adjustable drill stop and an $8 \mathrm{~mm}$ drill. In each specimen, the extractions were performed at 7 different depths, as shown in Table 4.

Table 4. Extraction depths to determine chloride content.

\begin{tabular}{cccccccc}
\hline Point & P1 & P2 & P3 & P4 & P5 & P6 & P7 \\
\hline Depth $(\mathrm{mm})$ & $0-2$ & $2-5$ & $5-8$ & $8-11$ & $11-14$ & $14-17$ & $17-20$ \\
\hline
\end{tabular}

The determination of chloride content was carried out through potentiometry using a silver/silver chloride electrode, with an accuracy of $0.01 \%$. From the chloride profile, the apparent diffusion coefficient $\left(D_{a}\right)$ can be determined by adjusting Equation 1 to the chloride content values measured by non-linear regression using the least square method. 
$C(x, t)=C_{S}-\left(C_{S}-C_{i}\right) \operatorname{erf}\left(\frac{x}{\sqrt{4 D_{a} t}}\right)$

where $C(x, t)=$ chloride concentration at the depth $x$ after the time $t(\%) ; C_{S}=$ chloride content on the concrete surface (\%); $C_{i}=$ initial chloride content in concrete (\%); erf = Gauss error function; $x$ = distance between the concrete surface and the mid-layer depth (m); $D_{a}=$ apparent diffusion coefficient $\left(\mathrm{m}^{2} / \mathrm{s}\right)$; and $t=$ exposure time (s).

\subsubsection{Non-steady-state diffusion coefficient - Rapid chloride migration test}

The non-steady-state diffusion coefficient $\left(D_{n s s m}\right)$ was determined based on the method proposed by Tang [26] and later standardized by NT Build 492 [12]. Among the test methods adopted in this paper, this is the one that requires less time, with a duration that can vary between 6 and $96 \mathrm{~h}$, according to the concrete characteristics. Although this method is widely disseminated and consolidated, it should be noted that the determination of the $D_{n s s m}$ depends on the depth of chloride penetration using silver nitrate $\left(\mathrm{AgNO}_{3}\right)$ spray. The colorimetric method using $\mathrm{AgNO}_{3}$ is a recurring reason for divergences in the literature, as it can present false-positive results in case of concrete carbonation [27], [28]. However, false-positive results due to carbonation tend to be observed close to the surface of the concrete sample, at depths significantly less than the chloride penetration depths recorded in the method prescribed by NT Build 492 [12].

To perform the test, four samples of $\phi 100 \times 50 \mathrm{~mm}$ from each concrete mix were used. Initially the specimens were subjected to a voltage of $30 \mathrm{~V}$, which was adjusted according to the current measured initially, which could vary between 10 and $60 \mathrm{~V}$. The temperatures of the anodic solution were also measured at the beginning and at the end of the procedure. Figure 3 shows the realization of the first stage of the test, in which the concretes are exposed to chlorides. After being subjected to ionic migration, the samples were diametrically broken and $0.1 \mathrm{M} \mathrm{AgNO}_{3}$ solution was sprayed on them to check the chloride penetration depth.

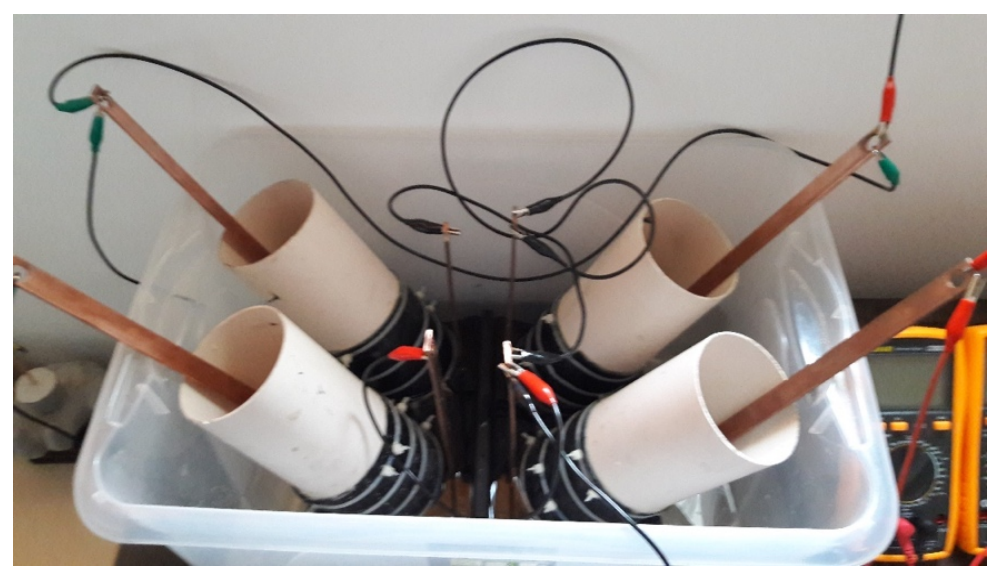

Figure 3. Execution of the NT Build 492 test method.

Lastly, the $D_{n s s m}$ was calculated using Equation 2

$D_{n s s m}=\frac{0.0239(273+T) L}{(U-2) t}\left(x_{D}-0.0238 \sqrt{\frac{(273+T) L x_{D}}{U-2}}\right)$

where $D_{n s s m}=$ non-steady state diffusion coefficient $\left(\times 10^{-12} \mathrm{~m}^{2} / \mathrm{s}\right) ; T=$ average value of the initial and final temperatures in the anolyte solution $\left({ }^{\circ} \mathrm{C}\right) ; L=$ thickness of the specimen $(\mathrm{mm}),_{U}=$ absolute value of the applied voltage $(\mathrm{V}) ; x_{D}=$ average value of the penetration depths $(\mathrm{mm})$; and $t=$ test duration (h). 


\subsubsection{Chloride diffusion coefficient - Multiregime test method}

The multiregime test method, initially proposed by Castellote et al. [29] and consolidated by UNE 83987 [13], was used to determine the steady state and the non-steady state diffusion coefficients of concretes. Three samples of $\phi 100$ x $30 \mathrm{~mm}$ from each concrete mix were used. Due to an operational problem, it was not possible to evaluate SF 20 concrete when this test was performed.

This method consists of the evaluation of chloride migration between two chambers with different chloride concentrations, under the application of a $12 \mathrm{~V}$ electric potential difference. One of the cells was filled with $1 \mathrm{M} \mathrm{NaCl}$ solution and the other filled with distilled water. Figure 4 shows the performance of the test.

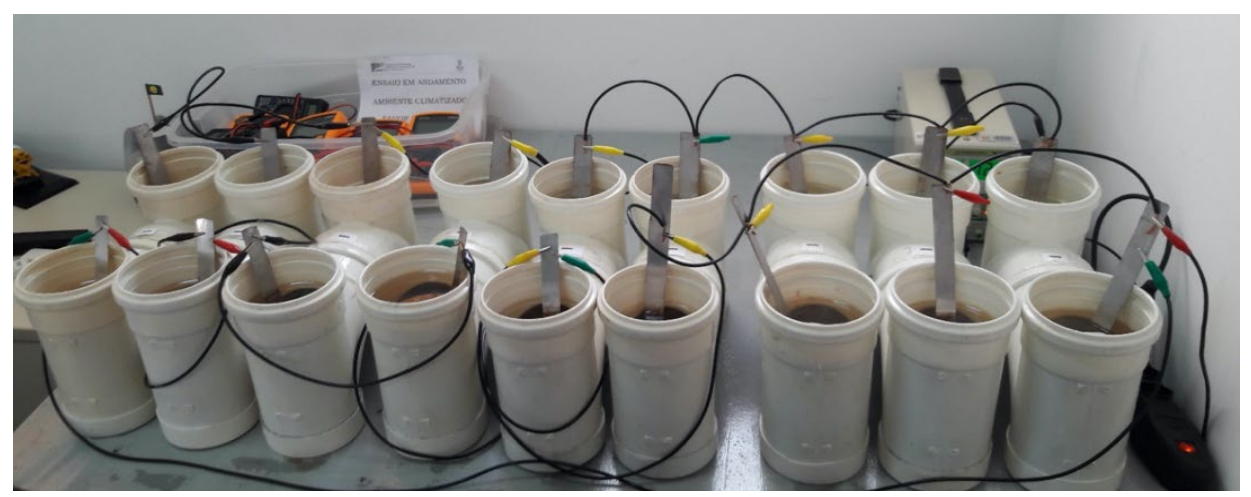

Figure 4. Execution of the multiregime test method.

The chloride concentration in the anodic cell was determined through the relationship between the conductivity of water and the chloride concentration, as shown in Figure 5. The values shown in Figure 5 were obtained in a laboratory environment, at a temperature of $23 \pm 2{ }^{\circ} \mathrm{C}$, using distilled water and $\mathrm{NaCl}$.

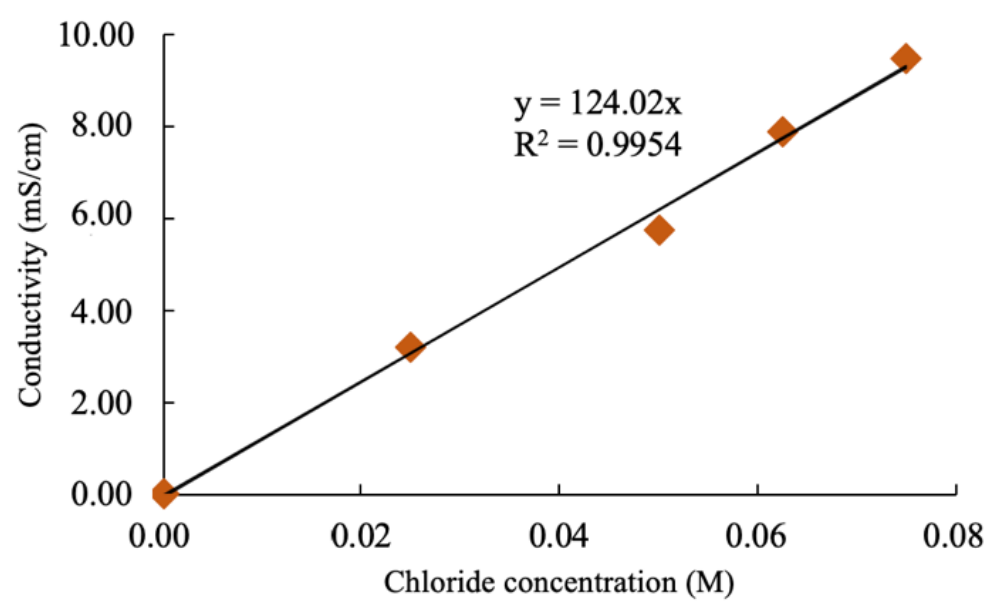

Figure 5. Adjustment for determining chloride concentration based on water conductivity.

The measurement of water conductivity was performed periodically using a digital conductivity meter. In the first moments of the test, the chloride concentration in the anodic cell is low and increases slowly, characterizing the nonsteady state. Then, the ions flux becomes constant, indicating the steady state. The time-lag $(\tau)$, for the case of chlorides transport, is defined as the time required for ionic flow through the concrete to become constant [30], [31]. Figure 6 schematically presents the methodology for determining the time-lag. 


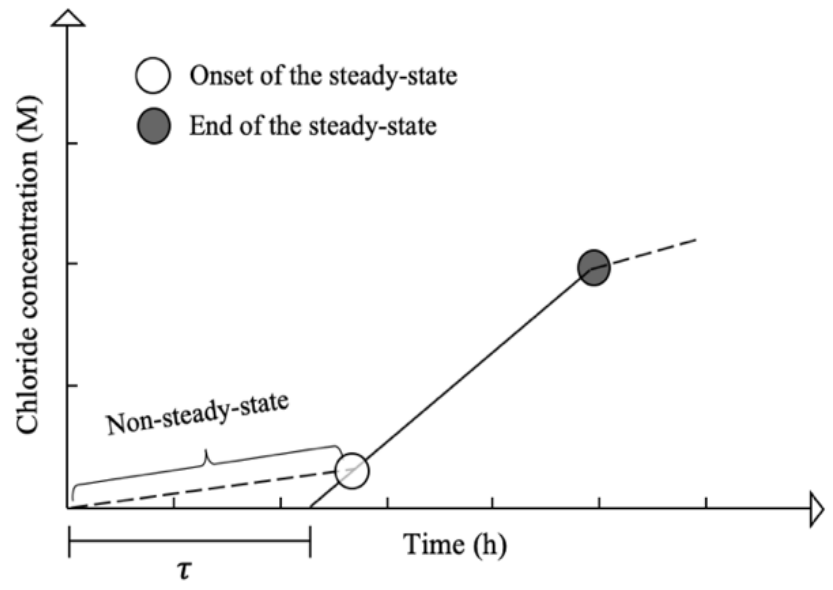

Figure 6. Scheme for determining the time-lag $(\tau)$, the steady-state, and non-steady-state (Adapted from Ribeiro et al. [30]).

The non-steady state diffusion coefficient $\left(D_{n s}\right)$ was determined based on Equation 3. In turn, the steady state diffusion coefficient was calculated using the modified Nernst-Planck equation, presented in Equation 5.

$D_{n s}=\frac{2 l^{2}}{\tau v^{2}}\left[v \operatorname{coth} \frac{v}{2}-2\right]$

where $D_{n s}=$ non-steady-state diffusion coefficient $\left(\mathrm{cm}^{2} / \mathrm{s}\right) ; \iota=$ thickness of the sample $(\mathrm{cm}) ; \tau=$ time-lag $(\mathrm{s})$; and $v$ is calculated according to Equation 4.

$v=\frac{z e \Delta \Phi}{k T}$

where $z=$ valence of ions (= 1 for chlorides); $e=$ elementary charge $(\mathrm{C}) ; \Delta \Phi=$ average voltage $(\mathrm{V}) ; k=$ Boltzmann constant $(\mathrm{J} / \mathrm{K})$; and $T=$ temperature $(\mathrm{K})$.

$D_{s}=\frac{J_{C l} R T l}{z F C_{C l} \gamma \Delta \theta}$

where $D_{s}=$ steady state diffusion coefficient $\left(\mathrm{cm}^{2} / \mathrm{s}\right) ; J_{C l}=$ ions flux, calculated according to Equation 6 $\left(\mathrm{mol} /\left(\mathrm{cm}^{2} \times \mathrm{s}\right) ;{ }_{R}=\operatorname{gas}\right.$ constant $(\mathrm{cal} /(\mathrm{mol} \times \mathrm{K})) ;{ }_{T}=$ temperature $(\mathrm{K}) ;{ }_{l}=$ thickness of the sample $(\mathrm{cm}) ; z=$ valence of ions (=1 for chlorides); $F=$ Faraday constant (cal/(volt $\times$ eq) $) ; C_{C l}=$ chloride concentration in the cathode cell $\left(\mathrm{mol} / \mathrm{cm}^{3}\right) ; \gamma=$ coefficient of activity of the cathodic cell solution $(=0.657$ for chloride $)$; and ${ }_{\Delta \theta}=$ average voltage across de sample (V).

$J_{C l}=\frac{V}{A} \frac{d C}{d t}$

where $J_{C l}=$ ions flux $\left(\mathrm{mol} /\left(\mathrm{cm}^{2} \times \mathrm{s}\right)\right) ; V=$ cathode cell volume $\left(\mathrm{cm}^{3}\right) ; A=$ sample section area exposed to ions $\left(\mathrm{cm}^{2}\right)$; e $d C / d t=$ slope of the linear part of the chloride concentration $v s$. time graph. 


\section{RESULTS AND DISCUSSIONS}

\subsection{Compressive strength and water absorption by capillarity}

The results obtained in the tests of compressive strength and capillary water absorption, performed at 126 days, are shown in Table 5.

Table 5. Compressive strength $\left(f_{c m}\right)$ and capillary water absorption of concretes.

\begin{tabular}{|c|c|c|}
\hline Mix & $f_{c m}(\mathbf{M P a})$ & Capillary water absorption after $72 \mathrm{~h}\left(\mathrm{~g} / \mathrm{cm}^{2}\right)$ \\
\hline $\mathrm{R} 45$ & 63.22 & 1.15 \\
\hline SF 5 & 63.46 & 1.04 \\
\hline SF 10 & 70.88 & 1.01 \\
\hline SF 20 & 74.51 & 0.91 \\
\hline R 55 & 46.57 & 1.35 \\
\hline R 65 & 40.60 & 1.77 \\
\hline
\end{tabular}

It can be seen, based on the data presented in Table 5, that, in general, silica fume increased the compressive strength and reduced the capillary water absorption of concretes. These improvements occur due to the pozzolanic reaction between $\mathrm{Ca}(\mathrm{OH})_{2}$ from cement hydration and $\mathrm{SiO}_{2}$ present in silica fume, providing the formation of secondary CSH. Also, silica fume acts as filler, modifying the concrete microstructure and making the paste more homogeneous. Similar results were observed by Meddah et al. [32], Poon et al. [33], and Shekarchi et al. [34].

It should be noted that the variation in compressive strength between some concretes is quite small (less than $1 \mathrm{MPa}$ in the case of R 45 and SF 5 concretes). This difference is quite small when analyzing the degree of precision of the test method in question.

\subsection{Apparent diffusion coefficient - Immersion test}

Figure 7 shows the chloride penetration profiles obtained from the powder extracted from the specimens submitted to the diffusion test standardized by ASTM C1556 [14]. These profiles are necessary for the calculation of $D_{a}$. The values of $D_{a}$, in turn, are shown in Table 6. Since the standard that governs this method does not present any classification of the penetrability of chlorides in concrete based on the diffusion coefficient, the classification proposed by Nilsson et al. [35] were used.

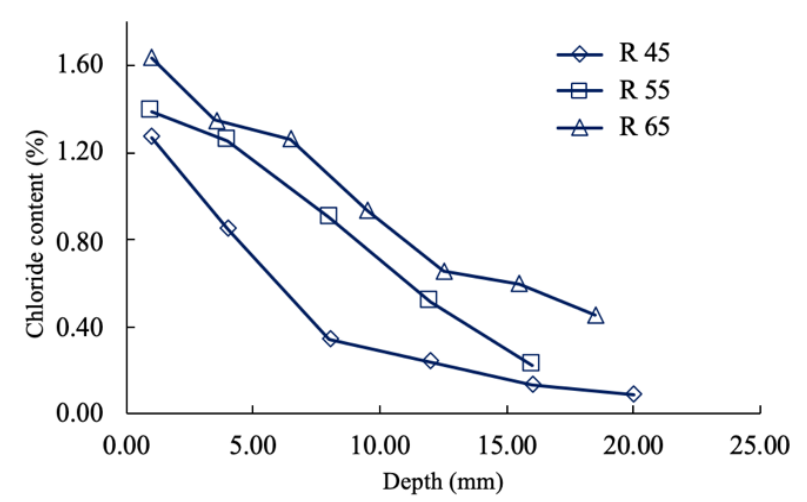

(a)

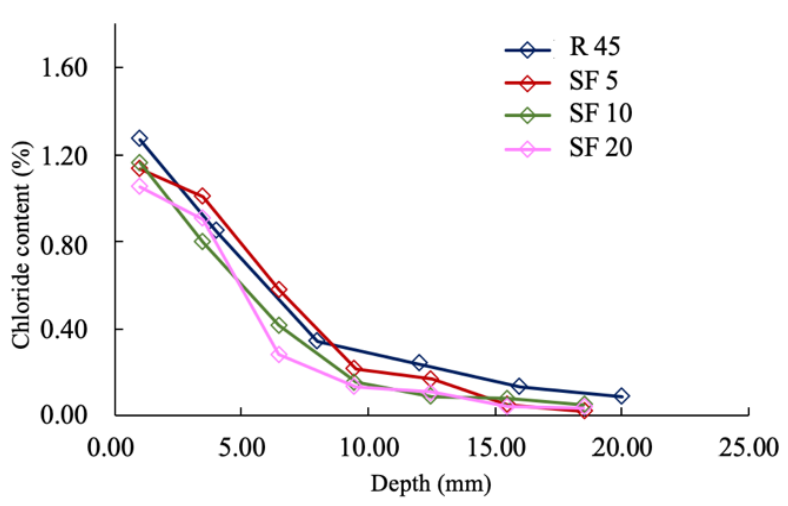

(b)

Figure 7. Chloride profiles obtained through potentiometry: (a) influence of the w/b ratio; (b) influence of the silica fume content. 
Table 6. Apparent diffusion coefficients ( $\boldsymbol{D}_{\boldsymbol{a}}$ ) obtained through ASTM C1556 [14] test method.

\begin{tabular}{ccc}
\hline Mix & $D_{a}\left(\times \mathbf{1 0}^{-\mathbf{1 2}} \mathbf{~}^{\mathbf{2}} / \mathbf{s}\right)$ & Resistance to chloride penetration [35] \\
\hline R 45 & 3.23 & Very high \\
\hline SF 5 & 2.85 & Very high \\
\hline SF 10 & 1.91 & Extremely high \\
\hline SF 20 & 1.81 & Extremely high \\
\hline R 55 & 7.99 & High \\
\hline R 65 & 13.48 & Moderate \\
\hline
\end{tabular}

It is noteworthy that the results obtained in the immersion test method are those that best represent the real conditions of exposure of the concrete to chloride-rich environments, since the ions penetrate the material mainly by diffusion. However, to obtain chloride profiles with a penetration depth that would allow a satisfactory evaluation, 112 days of immersion were necessary, which is, therefore, a considerably slower test than the other tests covered in this paper.

\subsection{Non-steady-state diffusion coefficient - Rapid chloride migration test}

The $D_{n s s m}$ values obtained and the classification of the concretes in terms of resistance to chloride penetration are shown in Table 7. It is noteworthy that all the concretes evaluated in this paper required tests lasting no longer than 48 $\mathrm{h}$. Thus, this is a test method capable of providing information about the durability-related characteristics of concrete in its early ages.

Table 7. Non-steady-state diffusion coefficient ( $\boldsymbol{D}_{\boldsymbol{n} \text { ssm }}$ ) obtained through NT Build 492 [12] test method.

\begin{tabular}{ccc}
\hline Mix & $D_{\text {nssm }}\left(\times \mathbf{1 0}^{-\mathbf{1 2}} \mathbf{~ m}^{\mathbf{2}} \mathbf{s}\right)$ & Resistance to chloride penetration [35] \\
\hline R 45 & 2.85 & Very high \\
\hline SF 5 & 1.75 & Extremely high \\
\hline SF 10 & 0.90 & Extremely high \\
\hline SF 20 & 0.20 & Extremely high \\
\hline R 55 & 4.76 & Very high \\
\hline R 65 & 6.02 & High \\
\hline
\end{tabular}

\subsection{Chloride diffusion coefficient - Multiregime test method}

Figure 8 shows the evolution of the chloride concentration in the anodic cell over time. Although it does not directly express the steady state and non-steady state diffusion coefficients, the analysis of the evolution of the chloride concentration allows to infer in a comparative way about the resistance of concretes to the penetration of ions. In this case, the more attenuated the curve is, the greater the difficulty imposed by the concrete on the passage of the ions.

The values of time-lag, ions flux, $D_{s}$ e $D_{n s}$, calculated from the data presented in Figure 8, are presented in Table 8. Attention should be paid to the fact that, in Table 8 , the classification of concretes in terms of resistance to chloride penetration was performed considering only the values of $D_{n s}$, since the classification in question was originally proposed to be related to non-steady state diffusion coefficients. 


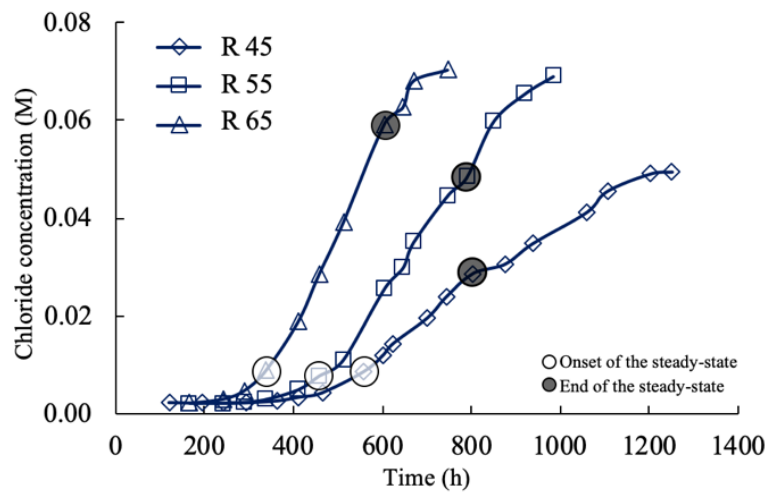

(a)

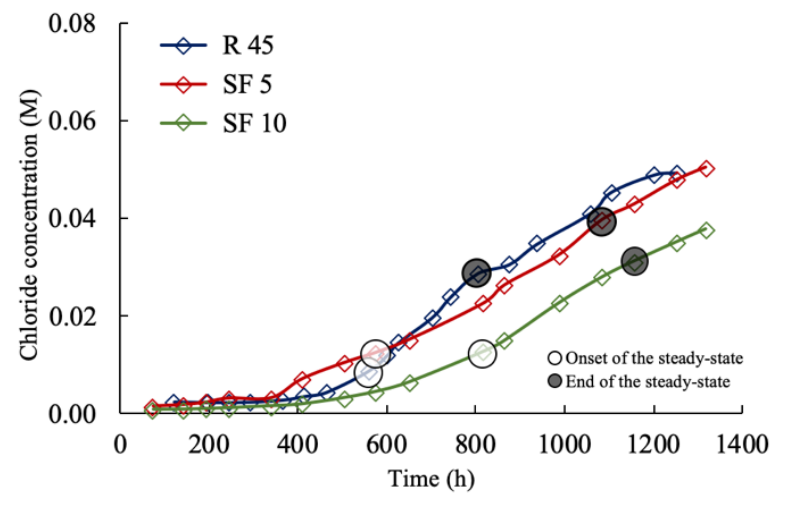

(b)

Figure 8. Evolution of chloride concentration in the anodic cell: (a) influence of the w/b ratio; (b) influence of the silica fume content.

Table 8. Chloride diffusion coefficients (steady-state and non-steady-state) obtained through UNE 83987 [13] test method.

\begin{tabular}{cccccc}
\hline Mix & Time-lag (h) & $\begin{array}{c}\text { Ions flux }\left(\times \mathbf{1 0}^{-\mathbf{1 0}}\right. \\
\left.\mathbf{m o l} /\left(\mathbf{c m}^{\mathbf{2}} \times \mathbf{s}\right)\right)\end{array}$ & $D_{s}\left(\times \mathbf{1 0}^{-\mathbf{1 2}} \mathbf{~ m}^{\mathbf{2}} \mathbf{s}\right)$ & $D_{n s}\left(\times \mathbf{1 0}^{-\mathbf{1 2}} \mathbf{~ m}^{\mathbf{2}} / \mathbf{s}\right)$ & $\begin{array}{c}\text { Resistance to chloride } \\
\text { penetration }\left(D_{n s}\right)\end{array}$ \\
\hline R 45 & 465 & 4.37 & 0.83 & 2.26 & Extremely high \\
\hline SF 5 & 485 & 3.32 & 0.63 & 2.17 & Extremely high \\
\hline SF 10 & 585 & 2.88 & 0.55 & 1.80 & Extremely high \\
\hline R 55 & 410 & 6.01 & 1.15 & 2.57 & Very high \\
\hline R 65 & 315 & 9.54 & 1.82 & 3.34 & Very high \\
\hline
\end{tabular}

When evaluating the data presented in Table 8, it is necessary to note the difference between the values of $D_{s}$ and $D_{n s}$. Castellote and Andrade [2] point out that it is of great importance to understand the difference between the coefficients measured in steady state and non-steady state, especially when these will be adopted as an input parameter in service life prediction models. In the case of the concretes evaluated in this paper, the values of $D_{n s}$ are noted, on average, 2.7 times higher than the values of $D_{s}$.

\subsection{General evaluation of the test methods for determining chloride diffusion coefficient}

The results obtained through the three test methods and the classification of the concretes in terms of their resistance to chloride penetration are shown in Figure 9. The values of $D_{a}, D_{n s s m}$ e $D_{n s}$, previously presented in Tables 6, 7, and 8 , respectively, were omitted for a better overview of the results.

It can be seen, based on Figure 9, that the test methods prescribed by NT Build 492 [12] and UNE 83987 [13] show lower results than those obtained using the method standardized by ASTM C1556 [14]. This fact was also observed by Castellote and Andrade [2]. Yuan and Santhanam [8], in turn, observed higher diffusion coefficients for the same concrete when using migration methods. These facts may be related to the type or content of mineral addition used and the curing process adopted since, according to Yuan [36], the migration-based test methods appear to be quite sensitive to the resistivity of concrete, with the diffusion coefficient being linked to the initial current. Even so, it is emphasized again that the immersion method, even though it is an accelerated test, is what tends to present results closer to those obtained in real structures, since there is no imposition of electric potential difference. The multiregime test method, in turn, is the one with the lowest average diffusion coefficient. 


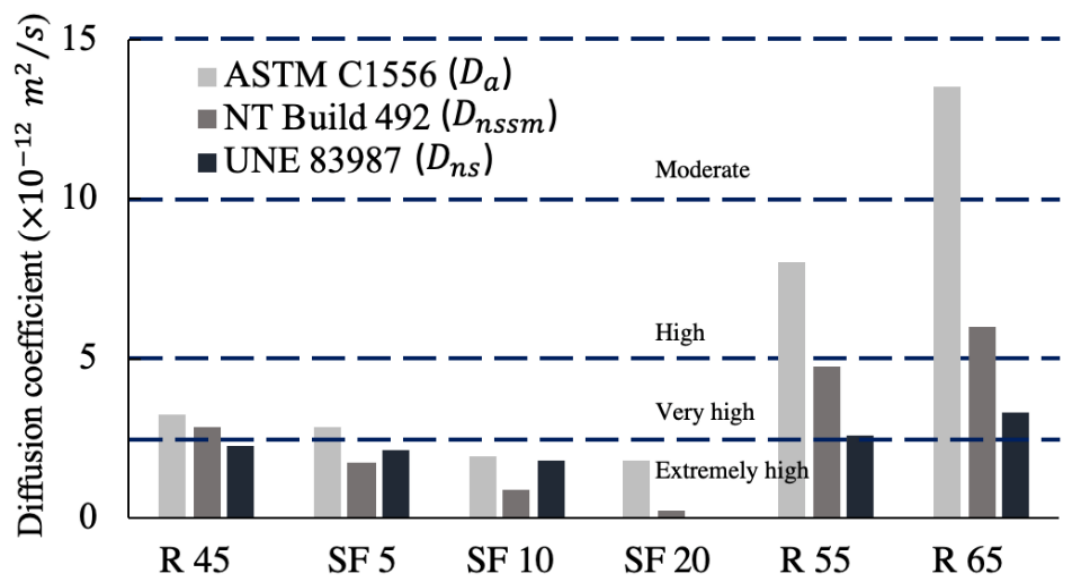

Figure 9. Panorama of the diffusion coefficients obtained through the three test methods.

It is also noted that, in general, the difference between the diffusion coefficients determined by the three methods is significantly greater when evaluating the concretes that tend to have greater penetrability - namely, R 55 and R 65 . As for the concretes that follow prescriptive parameters related to chloride environments (case of the mixes R 45, SF 5, SF 10 , and SF 20), the values of $D_{a}, D_{n s s m}$ and $D_{n s}$ are closer.

When analyzing the classification of concretes in terms of diffusivity, it is observed that, because of variations in diffusion coefficients, there are also differences in this parameter. It appears that only SF 10 has the same classification (extremely high) when evaluated by the three methodologies. The mix R 65, however, presented three different classifications, because of the wide variation in the diffusion coefficients obtained for this concrete.

In general, the partial replacement of cement by silica fume significantly reduced the diffusion coefficients determined through the three methods. This fact was already expected due to the physical and chemical performance of the fine particles of silica fume, refining the microstructure of the concrete and reducing its diffusivity, as also reported by several authors [32]-[34],[37]. When evaluating concretes with different $\mathrm{w} / \mathrm{b}$ ratios, the expected increase in the penetrability of concretes due to the increase in the $\mathrm{w} / \mathrm{b}$ ratio is also confirmed. It is noteworthy, however, that the $\mathrm{R} 65$, with the highest $\mathrm{w} / \mathrm{b}$ ratio, was the one that showed the greatest divergence in the diffusion coefficients measured experimentally.

Finally, Figure 10 shows the correlation between the three tests performed. The ASTM C1556 [14] test method was taken as a reference because this is an assay in which the chloride penetration occurs mainly by diffusion.

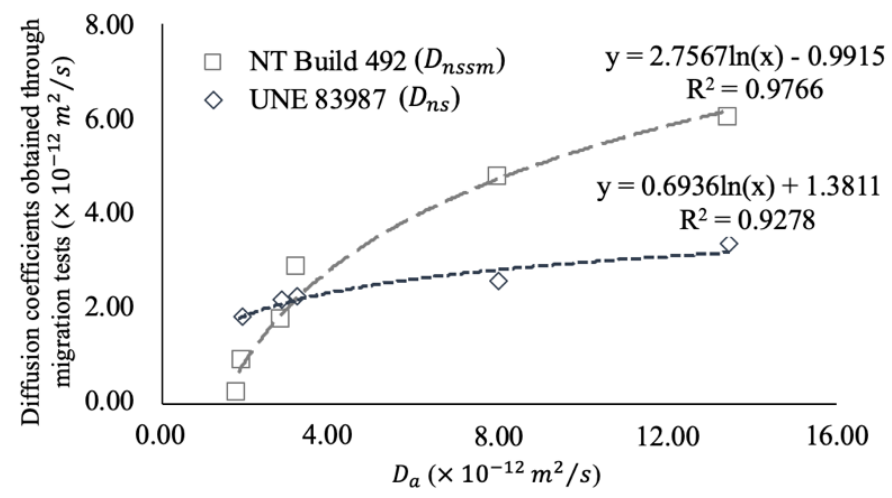

Figure 10. Correlation between the results obtained through the different test methods performed. 
It can be seen, from Figure 10, that the test method standardized by NT Build 492 [12], despite being the method that uses the greatest electric potential differences and depending on the colorimetric test with silver nitrate spray, is the one that has the best correlation with the diffusion test $\left(\mathrm{R}^{2}=0.9766\right)$. It is noteworthy that this method presents the simplest basis for its realization, requires less equipment, and demands less time than the other tests. In addition, the $D_{n s s m}$ values presented a coefficient of variation (COV) lower than that obtained in the multiregime test method namely, $\mathrm{COV}_{\text {Dnssm }}=9.98 \%$; $\mathrm{COV}_{\text {Dns }}=19.95 \%$.

\section{CONCLUSIONS}

In this paper, three standardized test methods for determining concrete chloride diffusion coefficient and their correlations were evaluated. The main conclusions stand out:

- The test methods for determining concrete chloride diffusion coefficient analyzed in this study showed a good correlation, with $\mathrm{R}^{2}$ greater than 0.90 . It should be noted that the method described in NT Build 492 [12] has a greater correlation with the diffusion test, with $\mathrm{R}^{2}=0.9766$. In addition, it was inferred that, when analyzing concrete less resistant to chloride penetration, the greater the discrepancy between the values presented by the three methods;

- In general, the multiregime test method showed the lowest non-steady state diffusion coefficients and the lowest correlation with the immersion test. This fact must be considered because the consideration of a very low diffusivity can induce structural designers to reduce the requirements regarding other aspects that contribute to the concrete durability, such as the cover depth and, thus, accentuate the reduction of the performance of the structural element over time;

- The use of chloride diffusion coefficients in service life prediction models needs special attention, since variations in diffusion coefficients, such as those presented in this paper, can significantly influence the service life prediction, the durability design, and the maintenance plan of the structures, especially when exposed to harsh environments;

- The use of silica fume in partial replacement of cement, in turn, corroborating with the data of several authors, generated reductions in the diffusivity of concretes when using the three test methods;

- Finally, the importance of using the durability indicators and the performance-based approach for concrete durability is highlighted. It was found that concretes that follow the same prescriptive parameters, such as w/b ratio and compressive strength, as observed in the mixes R 45 and SF 5, can show significantly different performances when evaluated from the perspective of durability.

\section{ACKNOWLEDGEMENTS}

The authors thank the Laboratório de Química dos Materiais (LQM) at the Universidade Federal do Rio Grande (FURG) for its assistance in carrying out the potentiometry test to determine the chloride profiles.

\section{REFERENCES}

[1] M. G. Alexander, "Service life design and modelling of concrete structures-background, developments, and implementation," Rev. ALCONPAT, vol. 8, no. 3, pp. 224-245, Sep 2018. http://dx.doi.org/10.21041/ra.v8i3.325.

[2] M. Castellote and C. Andrade, "Round-Robin test on methods for determining chloride transport parameters in concrete," Mater. Struct., vol. 39, no. 10, pp. 955, Oct 2006. http://dx.doi.org/10.1617/s11527-006-9193-x.

[3] V. Baroghel-Bouny et al., "Easy assessment of durability indicators for service life prediction or quality control of concretes with high volumes of supplementary cementitious materials," Cement Concr. Compos., vol. 33, no. 8, pp. 832-847, Sep 2011. http://dx.doi.org/10.1016/j.cemconcomp.2011.04.007.

[4] H. Beushausen, R. Torrent, and M. G. Alexander, "Performance-based approaches for concrete durability: State of the art and future research needs," Cement Concr. Res., vol. 119, pp. 11-20, May 2019. http://dx.doi.org/10.1016/j.cemconres.2019.01.003.

[5] G. B. Wally, et al., "Avaliação de indicadores de durabilidade de concretos com sílica ativa", in $61^{\circ}$ Cong. Bras. Concr., Fortaleza, Oct., 2019.

[6] Associação Brasileira de Normas Técnicas, Projeto de estruturas de concreto - Procedimento, NBR 6118, 2014.

[7] G. B. Wally, F. C. Magalhães, and L. C. P. Silva Fo., "Conceitos e aspectos da abordagem com base no desempenho na avaliação da durabilidade de estruturas de concreto armado expostas a ambientes agressivos", Rev. Concreto \& Construções, vol. 100, pp. 81-85, Dec., 2020. http://dx.doi.org/10.4322/1809-7197.2020.100.0006.

[8] Q. Yuan and M. Santhanam, "Test methods for chloride transport in concrete", in Performance of Cement-based Materials in Aggressive Aqueous Environments - State-of-the-art Report, RILEM TC 211-PAE, M. Alexander, A. Bertron, N. de Belle, Eds., New York, USA: Springer, 2013, ch. 13, pp. 319-343. 
[9] L. Tong and O. E. Gjørv, "Chloride diffusivity based on migration testing," Cement Concr. Res., vol. 31, no. 7, pp. 973-982, Jul 2001. http://dx.doi.org/10.1016/S0008-8846(01)00525-7.

[10] G. R. Meira and P. R. R. Ferreira, "Revisão sobre ensaios acelerados para indução da corrosão desencadeada por cloretos em concreto armado," Amb. Cons., vol. 19, no. 4, pp. 223-248, Oct 2019. http://dx.doi.org/10.1590/s1678-86212019000400353.

[11] D. V. Ribeiro, J. A. Labrincha, and M. R. Morelli, "Chloride diffusivity in red mud-ordinary Portland cement concrete determined by migration tests," Mater. Res., vol. 14, no. 2, pp. 227-234, May 2011. http://dx.doi.org/10.1590/S1516-14392011005000026.

[12] Nordtest, Concrete, Mortar and Cement-based Repair Materials: Chloride Migration Coefficient from Non-steady-state Migration Experiments, NT Build 492, 1999.

[13] Asociación Española de Normalización, Determinación de los Coeficientes de Difusión de los Iones Cloruro en el Hormigón Endurecido - Método multiregimen, UNE 83987, 2012.

[14] American Society for Testing and Materials, Standard Test Method for Determining the Apparent Chloride Diffusion Coefficient of Cementitious Mixtures by Bulk Diffusion, ASTM C1556, 2016.

[15] Associação Brasileira de Normas Técnicas, Agregados para Concreto - Especificação, NBR 7211, 2009.

[16] Associação Brasileira de Normas Técnicas, Agregados - Determinação da Composição Granulométrica, NBR NM $248,2003$.

[17] Associação Brasileira de Normas Técnicas, Agregado Miúdo - Determinação da Massa Específica e Massa Específica Aparente, NBR NM 52, 2009.

[18] Associação Brasileira de Normas Técnicas, Agregado Graúdo - Determinação da Massa Específica, Massa Específica Aparente e Absorção de Água, NBR NM 53, 2009.

[19] Associação Brasileira de Normas Técnicas, Agregados - Determinação da Massa Unitária e do Volume de Vazios, NBR NM 45, 2006.

[20] P. R. L. Helene and P. Terzian, Manual de Dosagem e Controle do Concreto. São Paulo, SP: Pini, 1992.

[21] Associação Brasileira de Normas Técnicas, Concreto - Procedimento para Moldagem e Cura de Corpos de Prova, NBR 5738, 2016.

[22] American Society for Testing and Materials, Standard Test Method for Determining Volume Fraction by Systematic Manual Point Count, ASTM E562, 2011.

[23] D. V. Ribeiro, "Influência da adição de lama vermelha nas propriedades e na corrosibilidade do concreto armado," Ph.D. thesis, Prog. Pós-grad. Ciênc. Eng. Mat., Univ. Fed. S. Carlos, São Carlos, Brasil, 2010.

[24] Associação Brasileira de Normas Técnicas, Concreto - Ensaio de Compressão de Corpos de Prova Cilíndricos, NBR $5739,2018$.

[25] Associação Brasileira de Normas Técnicas, Argamassa e Concreto Endurecidos - Determinação da Absorção de água por Capilaridade, NBR 9779, 2012.

[26] L. Tang, "Electrically accelerated methods for determining chloride diffusivity in concrete," Mag. Concr. Res., vol. 48, no. 176, pp. 173-179, Sep 1996. http://dx.doi.org/10.1680/macr.1996.48.176.173.

[27] L. V. Real et al., "Método colorimétrico por aspersão de nitrato de prata para avaliação da penetração de cloretos em concreto: estado da arte," Rev. ALCONPAT, vol. 5, no. 2, pp. 149-159, May 2015. http://dx.doi.org/10.21041/ra.v5i2.84.

[28] M. H. F. Medeiros, G. C. Réus, and C. V. Pontes, "Nitrato de prata como método colorimétrico para detecção da penetração de cloretos: análise crítica," in $3^{\circ}$ Simp. Paranaense de Patologia das Construções, Curitiba, 2018, pp. 186-197. http://dx.doi.org/10.4322/2526-7248.017.

[29] M. Castellote, C. Andrade, and C. Alonso, "Measurement of the steady and non-steady-state chloride diffusion coefficients in a migration test by means of monitoring the conductivity in the anolyte chamber - Comparison with natural diffusion tests," Cement Concr. Res., vol. 31, no. 10, pp. 1411-1420, Oct 2001. http://dx.doi.org/10.1016/S0008-8846(01)00562-2.

[30] D. V. Ribeiro, J. A. Labrincha, and M. R. Morelli, "Effect of the addition of red mud on the corrosion parameters of reinforced concrete," Cement Concr. Res., vol. 42, no. 1, pp. 124-133, Jan 2012. http://dx.doi.org/10.1016/j.cemconres.2011.09.002.

[31] N. S. Amorim Jr., et al., "Concrete containing recycled aggregates: Estimated lifetime using chloride migration test," Constr. Build. Mater., vol. 222, pp. 108-118, Oct 2019. http://dx.doi.org/10.1016/j.conbuildmat.2019.06.136.

[32] M. S. Meddah et al., "Performance evaluation of binary concrete designed with silica fume and metakaolin," Constr. Build. Mater., vol. 166, pp. 400-412, Mar 2018. http://dx.doi.org/10.1016/j.conbuildmat.2018.01.138.

[33] C. S. Poon, S. C. Kou, and L. Lam, "Compressive strength, chloride diffusivity and pore structure of high performance metakaolin and silica fume concrete," Constr. Build. Mater., vol. 20, no. 10, pp. 858-865, Dec 2006. http://dx.doi.org/10.1016/j.conbuildmat.2005.07.001.

[34] M. Shekarchi, A. Rafiee, and H. Layssi, "Long-term chloride diffusion in silica fume concrete in harsh marine climates," Cement Concr. Compos., vol. 31, no. 10, pp. 769-775, Nov 2009. http://dx.doi.org/10.1016/j.cemconcomp.2009.08.005.

[35] L. Nilsson, M. H. Ngo, and O. E. Gjørv, "High-performance repair materials for concrete structures in the port of Gothenburg", in Proc. 2nd Int. Conf. Concr. Under Severe Conditions: Environment and Loading, Sapporo, 1995, pp. 1193-1198. 
[36] Q. Yuan, "Fundamental studies on test methods for the transport of chloride ions in cementitious materials," Ph.D. thesis, Dept. Struct. Eng., Ghent Univ., Ghent, 2009.

[37] M. I. Khan and R. Siddique, "Utilization of silica fume in concrete: Review of durability properties," Resour. Conserv. Recycling, vol. 57, pp. 30-35, Dec 2011. http://dx.doi.org/10.1016/j.resconrec.2011.09.016.

Author contributions: FKSJ: conceptualization, methodology, formal analysis, writing; GBW: methodology, data curation, formal analysis, writing; FRT: conceptualization, methodology; FCM: conceptualization, methodology, formal analysis, writing, supervision;

Editors: Fernando Pelisser Guilherme Aris Parsekian. 